\title{
PENGARUH METODE PEMBELAJARAN DAN BERPIKIR KRITIS TERHADAP KEMAMPUAN MENULIS ARGUMENTASI
}

\author{
Dudu Suhandi Saputra \\ Dosen PGSD Universitas Majalengka \\ d.suhandi.s@gmail.com
}

\begin{abstract}
The purpose in this study is to learn the influence of learning method and critical thinking toward ability in writing argumentation. This study was conducted on $4^{\text {th }}$ grade students of SDN Sukapura 3 Cirebon in 2015 by taking 32 samples. Data is acquired using twoway varian analysis test (ANAVA) utilizing treatment by level $2 \times 2$ design. The result study showed that: (1) the writing argumentation skill student's problem based learning method is higher than that of using recitation method, (2) there is no interaction correlation between students' learning methods and their critical thinking, proven by their writing argumentation skill, (3) the writing argumentation skill students with higher critical thinking using problem based learning method is higher than using recitation method, (4) the writing argumentation skill students with lower critical thinking using problem based learning is higher than using recitation method. The results of this study illustrates that using problem based learning method by considering the their critical thinking can increase toward ability in writing argumentation.
\end{abstract}

Keyword: Learning method, think critical, ability writes argument

\begin{abstract}
Abstrak : Penelitian ini bertujuan untuk mengetahui pengaruh metode pembelajaran dan berpikir kritis terhadap kemampuan menulis argumentasi. Penelitian ini dilakukan pada siswa kelas IV SD Negeri Sukapura 3 Cirebon pada tahun 2015 dengan 32 sampel. Pengambilan data diperoleh melalui tes analisis Varian (ANAVA) dua jalur dengan desain treatmeant by level 2 $x$ 2. Hasil penelitian menunjukkan bahwa: (1) Hasil menulis argumentasi siswa yang menggunakan metode problem based learning lebih baik dari pada siswa yang menggunakan metode resitasi. (2) Tidak terdapat pengaruh interaksi anatara metode pembelajaran dengan kemampuan berpikir kritis terhadap kemampuan menulis argumentasi. (3) Hasil menulis argumentasi siswa yang berpikir kritis tinggi dan belajar dengan metode problem based learning lebih baik dari pada metode resitasi, (4) Hasil menulis argumentasi siswa yang berpikir kritis rendah dan belajar dengan metode problem based learning lebih baik dari pada metode resitasi. Hasil penelitian ini menunjukan bahwa dengan menggunakan metode problem based learning dengan mempertimbangkan kemampuan berpikir kritis siswa dapat meningkatkan kemampuan menulis argumentasi.
\end{abstract}

Kata kunci: Metode pembelajaran, berpikir kritis, kemampuan menulis argumentasi

Pendidikan merupakan suatu kebutuhan hidup dan bagaimana cara untuk bertahan pokok dalam kehidupan manusia, karena hidup.

dengan pendidikan, manusia bisa mengolah

akal pikirannya dengan pola yang terarah.

Melalui berpikir seseorang dapat menjalani
Pada hakikatnya pendidikan dilakukan sepanjang hayat, dalam arti lain bahwa pendidikan dilakukan manusia semenjak dilahirkan sampai akhir hayat. Selama rentan 
waktu tersebut pula manusia menjalani proses pembelajaran baik melalu pendidikan formal maupun non formal. Salah satu bentuk proses pembelajaran manusia yang pertama kali dialami adalah pemerolehan bahasa.

Bahasa merupakan suatu alat untuk melakukan komunikasi, baik secara verbal maupun non verbal. Bahasa memilki peranan penting dalam kehidupan sehari-hari guna melakukan kumonikasi dan berinteraksi dengan lingkungan sekitar, Bahasa dalam kehidupan manusia sangat memiliki peranan yang sentral. Malalui bahasa, manusia bisa melakukan hubungan sosial dengan optimal, bisa mengikuti perkembangan zaman dengan optimal.oleh sebab itu kemampuan dalam berbahasa sangat penting untuk dikembangkan dengan tujuan untuk kelancaran berkomunikasi dan berinteraksi dengan lingkungan sekitar. Pembelajaran bahasa terdiri atas empat aspek keterampilan bebahasa yaitu menyimak, berbicara, membaca, dan menulis.

Keterampilan menulis merupakan suatu keterampilan berbahasa yang dipergunakan untuk berkomunikasi secara tidak langsung. Sebagaimana dikemukakan oleh Tarigan (2008;3) bahwa "menulis merupakan suatu kegiatan yang produktif dan ekspresif." Selain itu menurut Tarigan mengemukakan bahwa keterampilan menulis merupakan suatu ciri orang terpelajar atau bangsa yang terpelajar. Hal ini diperkuat oleh Morsey (Tarigan;4) yang mengemukakan bahwa "menulis dipergunakan, melaporkan atau memberitahukan, dan mempengaruhi; dan maksud serta tujuan seperti itu hanya dapat dicapai dengan baik oleh orang-orang yang dapat menyusun pikirannya dan mengutamakannya dengan jelas, kejelasan ini bergantung pada pikiran, organisasi, pemakaian kata-kata, dan struktur kalimat."

Tarigan (2008:3) mengemukakan bahwa keterampilan menulis merupakan suatu keterampilan berbahasa yang dipergunakan untuk berkomunikasi secara tidak langsung. Sebagaimana dikemukana oleh Tarigan bahwa menulis merupakan suatu kegiatan yang produktif dan ekspresif. Selain itu menurut Tarigan mengemukakan bahwa keterampilan menulis merupakan suatu ciri orang terpelajar atau bangsa yang terpelajar. Hal ini diperkuat leh Morsey (Tarigan, 2008: 4) yang mengemukakan bahwa "menulis dipergunakan, melaporkan / memberitahukan, dan mempengaruhi; dan maksud serta tujuan seperti itu hanya dapat dicapai dengan baik oleh orang-orang yang dapat menyusun pikirannya dan mengutamakannya dengan jelas, kejelasan ini bergantung pada pikiran, organisasi, pemakaian kata-kata, dan struktur kalimat."

Keterampilan menulis tidak dapat diperoleh secara alamiah, tetapi harus dengan cara proses belajar mengajar. Kegiatan 
menulis merupakan salah satu kegiatan tidak dibaca, kegiatan menulis itu sia-sia. yang sifatnya berkelanjutan sebaga Mengajar menulis antara lain adalah pembelajaran pun perlu dilakukan secara membangun kesadaran bahwa menulis itu berkesinambungan sejak sekolah dasar. Fakta bergantung pada pembaca (reader dependent) tersebut merupakan dasar mengenai dan kualitas respon pembaca menentukan pandangan bahwa menulis merupakan keberhasilan komunikasi tulis. Belajar kemampuan dasar sebagai bekal menulis menulis ibarat seperti belajar keterampilan dijenjang berikutnya. Jika dilihat dari dasar lain yang berubah dari mudah ke sulit, dari pandangan mengenai pentingnya akan sini ke sana, dari sekarang ke nanti. Karena penguasaan keterampilan menulis tersebut, itu apa yang pertama ditulis adalah diri maka dalam proses pembelajaran menulis sendiri, rumah sendiri, keluarga sendiri dan perlu mendapatkan perhatian yang serius dari seterusnya.

guru itu sendiri khususnya di jenjang sekolah

Menulis hasil penelitian dengan dasar dengan tujuan supaya siswa dapat menggunakan sistematika argumentasi menguasai keterampilan menulis sejak dini, adalah langkah yang baik untuk menulis mereka mampu menghasilkan karya tulisan karangan argumentasi. Dasar sebuah tulisan yang produktif dimasa akan datang. yang bersifat argumentatif adalah berpikir Keterampilan berbahasa bertujuan untuk kritis dan logis. Untuk itu ia harus bertumpu menunjang komunikasi dan sosialisasi antar pada bukti-bukti atau evidensi yang dapat individu, betapa pentingnya kemampuan dijalin dalam metode-metode sebagaimana menulis oleh sebab itu seyogyanya perlu dipergunakan juga oleh eksposisi. Tetapi dikuasai oleh setiap individu semenjak dalam ber-argumentasi terdapat motivasi sekolah dasar.

Menulis merupakan keterampilan yang lebih kuat. Eksposisi hanya memerlukan kejelasan, sebab itu fakta-fakta berbahasa yang dipergunakan untuk dipakai hanya seperlunya. Namun berkomunikasi secara tidak langsung. argumentasi, di samping memerlukan Menulis merupakan kegiatan yang produktif kejelasan, keyakinan dengan perantara fakta dan ekspresif, sehingga penulis mampu - fakta / bukti-bukti itu, untuk itu kelompok memanfaatkan kemampuan dalam kami akan menjelaskan karangan menggunakan tata bahasa, struktur bahasa argumentasi sebagai penyelesaian tugas dan kosa kata. Tujuan menulis adalah menulis menyampaikan pesan kepada pembaca. Bila 
Keraf (2007:3) mengemukakan bahwa argumentasi merupakan suatu bentuk retorika dengan tujuan untuk dapat mempengaruhi sikap dan pendapat orang lain (pembaca) dengan tujuan supaya si pembaca percaya dan pada akhirnya dapat bertindak sesuai dengan apa yang diinginkan oleh si penulis itu sendiri.

Sinduwiryo dan A Rahman (Dhiksy, 2010;20) mengatakan bahwa menulis argumentasi adalah menyampaikan pendirian melalui tulisan dengan berusaha meyakinkan pembaca akan kebenaran pendapatnya dengan mengajukan alasan dan bukti sehingga pembaca terpengaruh, menerima sikap dan berbuat sesuai dengan kehendak penulis. Jadi kemampuan menulis argumentasi adalah kemampuan merangkai kata-kata menjadi kalimat yang baik, dalam hal ini dapat dipahami pembaca, menyusun kalimat secara jelas dan logis, mengungkapkan pendapat serta alasan berdasarkan fakta, sehingga dapat meyakinkan pembaca.

Salah satu permasalahan yang dihadapi pada saat pembelejaran menulis, Siswa mengalami hambatan berargumentasi dalam bentuk tulisan. Kemampuan berargumentasi merupakan bagian dari kemampuan berpikir kritis dan komunikasi dengan tujuan untuk meyakinkan atau membujuk pembaca. Permasalahan yang timbul ini disebabkan oleh metode pembelajaran yang digunakan

oleh guru pada saat pembelajaran berlangsung masih konvensional. Yaumi (2012:67) mengemukakan "berpikir kritis atau critical thinking adalah kemampuan kognitif untuk mengatakan sesuatu dengan penuh keyakinan karena bersandar pada alasan yang logis dan bukti empiris yang kuat." Kemampuan berpikir kritis dalam menulis argumentasi merupakan aspek yang sangat penting, hal ini didasarkan pada tujuan paragraf argumentasi itu sendiri yaitu untuk meyakinkan pembaca.

Yaumi (2012:294) mengemukakan bahwa "metode problem based learning (pembelajaran berbasis masalah) merupakan metode pembelajaran dengan pendekatan pembelajaran siswa pada masalah autentik sehingga siswa dapat menyusun pengetahuannya sendiri, menumbuh kembangkan keterampilan yang lebih tinggi dan inquiry, memandirikan siswa dan meningkatkan kepercayaan diri sendiri." Metode problem based learning dalam pembelajaran menulis argumentasi memiliki ciri-ciri; siswa diorientasikan pada masalah serta diberi bimbingan dalam proses belajar. Bimbingan diberikan langkah demi langkah yang terdiri atas lima tahap (mengorientasikan siswa terhadap masalah, mengorganisasi peserta didik untuk belajar, membimbing penyelidikan individual, mengembangkan dan menyajikan hasil 
menulis argumentasi, menganalisis dan mengevaluasi proses pemecahan masalah).

Mulyasa (2011:113) menyatakan bahwa metode resitasi atau disebut dengan penugasan merupakan cara penyajian bahan pelajaran, dengan cara guru memberikan seperangkat tugas yang harus dikerjakan peserta didik, baik secara individual maupun secara kelompok. Dasar pemikiran dari metode resitasi ini yaitu dengan memandang serta merasakan bahwa bahan pelajaran terlalu banyak, sementara waktu sedikit. Metode resitasi dalam pembelajaran menulis argumentasi merupakan metode yang berorientasi pada tujuan yang akan dicapai tanpa memberikan bimbingan secara cermat. Siswa menulis sesuai dengan instruksi dan petunjuk yang diberikan guru secara lisan dan tertulis selama waktu yang ditetapkan. Siswa diberi kebebasan dalam mengemukakan pendapat serta memberikan alasan sendiri sesuai dengan topik yang dipilihnya tanpa bantuan media dan hanya berorientasi pada petunjuk.

Berpikir kristis merupakan kemampuan seseorang untuk berpikir secara beralasan dan reflektif dengan menekankan pembuatan keputusan tentang apa yang harus dipercayai atau dilakukan. Orang yang memiliki kemampuan untuk berpikir secara kritis biasanya tidak langsung menerima sesuatu yang dianggap baru bagi dirinya.
Mereka akan lebih mempelajari secara mendalam tentang kebenaran sesuatu tersebut, dan bisasnya seseorang yang memiliki kemampuan untuk berpikir kritis akan memiliki tingkat kecerdasan yang baik.

Banyak manfaatnya jika seseorang mampu memiliki kemampuan untuk berpikir kritis, karena apabila seseorang yang memiliki kemampuan untuk berpikir kritis, akan menjalani setiap apa yang dia lakukan dengan penuh ketelitian, dan disinilah yang akan menjadikan seseorang yang berpikir kritis itu memiliki kelebihan dari orang lain.

\section{METODE}

Penelitian ini merupakan penelitian dengan menggunakan eksperimen dengan desain treatment by level $2 \times 2$. Pada eksperimen ini peneliti menggunakan dua metode pembelajaran yaitu metode problem based learning dan metode resitasi. Subjek penelitian dibagi kedalam dua kelas yaitu kelas ekperimen satu dengan pembelajaran menggunakan metode problem based learning dan kelas eksperimen dua dengan pembelajaran menggunakan metode resitasi, sedangkan variabel atribut diklasifikasin kedalam kategori berpikiri kritis tinggi dan rendah.

Jumlah keseluruhan siswa yang menjadi subjek penelitian adalah 60 orang siswa yang dibagi kedalam dua kelas 
diantaranya kelas A sebanyak 30 0rang dan kelas B sebanyak 30 orang. Selanjutnya siswa diberikan tes kemampuan berpikir kritis, skor dari hasil tes kemampuan berpikir kritis tersebut salanjutnya disusun berdasarkan urutan dari skor tertinggi ke skor yang terendah.

Selanjutnya, pada setiap kelas ditetapkan $27 \%$ dari rangking teratas digolongkan sebagai kelompok siswa yang memiliki kemampuan berpikir kritis tinggi dan $27 \%$ dari rangking terbawah digolongkan sebagai kelompok siswa yang memiliki kemampuan bepikir kritis rendah.

Dari tiap-tiap kelas diperoleh sebanyak $27 \%$ dari 30 orang yaitu 8 orang yang memiliki kemampuan berpikir kritis tinggi dan 8 orang yang memiliki kemampuan berpikir kritis rendah. Dengan demikian, maka distribusi siswa pada masing-masing taraf variabel bebas dapat dilihat pada table berikut ini:

Tabel 3.2 Distribusi Siswa Pada Masing-masing Variabel

\begin{tabular}{|c|c|c|c|}
\hline \multirow{2}{*}{$\begin{array}{l}\text { Kemampuan } \\
\text { berpikir kritis }\end{array}$} & \multicolumn{2}{|c|}{ Metode } & \multirow[t]{2}{*}{ Jumlah } \\
\hline & PBL & Resitasi & \\
\hline Tinggi & 8 & 8 & 16 \\
\hline \multirow[t]{2}{*}{ Rendah } & 8 & 8 & 16 \\
\hline & 16 & 16 & 32 \\
\hline
\end{tabular}

Hasil kemampuan menulis argumentasi diperoleh setelah tes keterampilan menulis argumentasi pada akhir pelaksanaan penelitian. Penilaian dalam keterampilan menulis argumentasi didasarkan pada rubrik keterampilan menulis argumentasi

Teknik analisis data yang digunakan dalam penelitian ini adalah teknik analisis varian (ANAVA) dua jalur. Teknik ini dipilih atas dasar tujuan peneliti untuk mengetahui perbedaan hasil kemampuan menulis argumentasi berdasarkan pada kelas pembelajaran (metode pembelajaran), perbedaan hasil kemampuan menulis berdasarkan tingkatan kemampuan berpikir kritis (tinggi dan rendah) dan kelas pembelajaran, serta guna mengetahui mengenai interaksi antara metode pembelajaran dan berpikir kritis terhadap kemampuan menulis argumentasi.

\section{HASIL}

Hasil analisis dan deskripsi, peneliti melihat adanya perbedaan hasil kemampuan menulis argumentasi antara siswa yang pembelajarannya menggunakan metode problem based learning dengan siswa yang pembelajarannya menggunakan metode resitasi. skor rata-rata hasil kemampuan menulis argumentasi untuk kelas problem based learning yaitu 17.6833 dengan standar deviasi 4,36973, skor maksimum untuk kelas 
Berpikir Kritis Terhadap Kemampuan Menulis Argumentasi

Dudu Suhandi Saputra

problem based learning yaitu 25,00 dan skor minimum 9,00 dengan median 18,5000. Skor rata-rata tersebut lebih tinggi dibandingkan dengan kelompok siswa yang pembelajarannya dengan menggunakan metode resitasi yaitu skor rata-rata 9,8833 dan standar deviasi 4,39569. Nilai maksimum untuk kelas resitasi yaitu 23,50 dan nilai minimum 5,00 dengan median 7,7500 .

Selain melihat kemampuan menulis argumentasi berdasarkan kelas pembelajaran, selanjutnya peneliti melihat kemampuan menulis argumentasi berdasarkan kemampuan berpikir kritis dan kelas pembelajaran.

Hal ini bertujuan guna melihat sejauh mana pengaruh antara kelas pembelajaran dan kemampuan berpikir kritis terhadap kemampuan menulis argumentasi. rata-rata hasil kemampuan menulis argumentasi berdasarkan kelas pembelajaran dan kemampuan berpikir kritis dapat dideskripsikan bahwa skor rata-rata hasil kemampuan menulis argumentasi untuk siswa yang memiliki kemampuan berpikir kritis tinggi dan belajar dengan menggunakan metode problem based learning yaitu 22,1875 dengan standar deviasi 1,66771, skor maksimum untuk siswa yang memiliki kemampuan berpikir kritis tinggi dan belajar dengan menggunakan metode problem based learning yaitu 25,00 dan skor minimum $20,50,00$ dengan median 21,7500. Skor ratarata tersebut lebih tinggi dibandingkan dengan kelompok siswa yang memiliki kemampuan berpikir kritis tinggi dan belajar dengan menggunakan metode resitasi yaitu skor rata-rata 11,5625 dan standar deviasi 6,60323. Nilai maksimum untuk kelas resitasi yaitu 23,50 dan nilai minimum 6,00 dengan median 9,0000.

Skor rata-rata hasil kemampuan menulis argumentasi kelompok siswa yang memiliki kemampuan berpikir kritis rendah dan belajar dengan menggunakan metode problem based learning yaitu 14,0625 dan standar deviasi 4,04826. Nilai maksimum kelompok siswa yang memiliki kemampuan berpikir kritis rendah dan belajar dengan menggunakan metode problem based learning yaitu 19,00 dan nilai minimum 9,00 dengan median 16,388. Skor rata-rata tersebut lebih tinggi dibandingkan dengan kelompok siswa yang memiliki kemampuan berpikir kritis rendah dan belajar dengan menggunakan metode resitasi yaitu skor ratarata 6,6250 dan standar deviasi 1,32961. Nilai maksimum untuk kelompok siswa yang memiliki kemampuan berpikir kritis rendah dan belajar dengan menggunakan metode resitasi yaitu 9,00 dan nilai minimum 5,00 dengan median 6,7500 . 
Hipotesis pertama yang diajukan dalam peneltian ini menunjukan bahwa $\mathrm{H}_{0}$ ditolak karena berdasarkan hasil uji non parametrik dengan menggunakan uji mann-whitney menunjukan bahwa nilai hasil uji Z yaitu 5,205 yaitu $<0,05$. Nilai uji asym. Sig. (2tailed) $0,000<0,05$ dengan demikian $\mathrm{H}_{0}$ ditolak dan dapat disimpulkan bahwa kemampuan menulis argumentasi kelompok siswa yang belajar dengan menggunakan metode problem based learning lebih tinggi dari pada kelompok siswa yang belajar dengan menggunakan metode resitasi. Hipotesis kedua yaitu melihat interaksi antara metode pembelajaran dan berpikir kritis terhadap kemampuan menulis argumentasi. Menunjukan adanya perbedaan yang sangat signifikan kemampuan menulis argumentasi berdasarkan kelompok kemampuan berpikir kritis. Selain dengn menggunakan uji kruskall wallis, guna melihat perbedaan kemampuan menulis argumentasi berdasarkan kelas pembelajaran dan kemampuan berpikir kritis berikut merupakan deskripsi uji tuckey mengenai perbedaan kemampuan menulis argumentasi berdasarkan kelas pembelajaran dan kemampuan menulis argumentasi menggunakan uji tuckey untuk menjawab hipotesis ketiga dan keempat menunjukan adanya perbedaan hasil kemampuan menulis argumentasi berdasarkan kelompok (grup) kemampuan berpikir kritis dan kelas pembelajaran, dapat disimpulkan bahwa hasil kemampuan menulis argumentasi kelompok siswa yang memiliki kemampuan berpikir kritis tinggi maupun rendah dan pembelajarannya menggunakan metode problem based learning lebih baik dari pada metode resitasi.

\section{PEMBAHASAN}

Hasil penelitian menunjukan bahwa tidak terdapat interaksi antara metode pembelajaran dan berpikir kritis terhadap kemampuan menulis argumentasi. Ini menunjukan bahwa metode pembelajaran memiliki kontribusi terhadap kemampuan menulis argumentasi siswa, kemudian berpikir kritis juga memiliki kontribusi terhadap kemampuan menulis argumentasi siswa. Hal ini didukung oleh pendapat Yaumi (2012;67) mengemukakan bahwa "berpikir kritis merupakan kemampuan kognitif untuk mengatakan sesuatu dengan penuh keyakinan karena bersandar pada alasan yang logis dan bukti empiris yang kuat." Kemampuan berpikir kritis pada siswa kelas IV sekolah dasar adalah kemampuan dalam pengenalan masalah, penilaian berdasarkan informasi dari berbagai sumber, dan menyimpulkan dengan penalaran logis.

Pembelajaran menulis khususnya menulis karangan argumentasi bertujuan agar siswa terampil dalam menuliskan gagasan, ide, pikiran, dan pendapatnya disertai dengan fakta-fakta sebagai bukti pendukung 
Berpikir Kritis Terhadap Kemampuan Menulis

Argumentasi

Dudu Suhandi Saputra

sehingga gagasan atau pendapatnya dapat diterima serta mempengaruhi pembaca. Untuk terampil menulis karangan argumentasi, sebaiknya siswa memahami terlebih dahulu hakikat sebuah karangan argumentasi itu sendiri, sehingga siswa dapat menulis karangan argumentasi yang sesuai dengan kriteria penulisan karangan argumentasi.

Pembelajaran menulis karangan argumentasi bertujuan agar siswa memahami karakteristik dan cara penulisan karangan argumentasi. Siswa terampil dalam menuangkan ide, gagasan, serta pendapatnya secara logis, siswa terampil dalam menghadirkan, menyeleksi, dan mengemukakan fakta-fakta untuk membuktikan kebenaran argumennya, siswa terampil menyampaikan pemecahan masalah dan simpulan yang logis, siswa juga diharapkan terampil menggunakan bahasa yang baik dan benar saat menulis. Diharapkan karangan argumentasi yang dihasilkan adalah karangan argumentasi yang benar sesuai dengan kriteria penulisan karangan argumentasi.

Seseorang perlu mendapat perhatian sejak tingkat pendidikan yang paling dasar agar dapat mengembangkan keterampilan menulis khususnya menulis karangan argumentasi. Keterampilan menulis tidak terbentuk secara otomatis, seseorang yang ingin terampil menulis memerlukan pembelajaran serta latihan yang teratur. Adanya harapan-harapan tersebut mendorong penulis untuk melihat langsung kenyataan yang ada di sekolah dan untuk mengetahui bagaimana tingkat keterampilan siswa dalam menulis karangan argumentasi, serta perilaku siswa saat mengikuti pembelajaran. Kenyataan di lapangan menunjukkan bahwa keterampilan siswa dalam menulis karangan, terutama karangan argumentasi masih banyak hal yang perlu ditingkatkan.

Rendahnya keterampilan siswa tersebut dapat diketahui antara lain siswa belum memahami benar hakikat karangan argumentasi, bagaimana karakteristik isi karangan argumentasi, serta bagaimana langkah-langkah menulis karangan argumentasi. Siswa belum terampil dalam menghadirkan latar belakang masalah dalam karangan, siswa belum terampil menyampaikan fakta untuk membuktikan pendapatnya, belum terampil menyimpulkan karangan pada bagian akhir tulisan argumentasi. Selain itu, siswa juga belum terampil dalam menggunakan ejaan bahasa Indonesia yang baik dan benar. Hal tersebut membuat minat siswa dalam menulis sangat rendah karena merasa menulis itu sulit. Guru mengaku masih banyak siswa yang berperilaku negatif saat mengikuti 
pembelajaran. Mereka lebih senang pembelajaran biasanya hanya tertulis bergurau, mengantuk, dan tidak serius dalam informasi secara sempit dan cenderung mengerjakan tugas-tugas. Adanya berupa poin-poin materi yang tertulis saja. kesenjangan antara harapan dan kenyataan Cara ini jelas tidak memicu siswa untuk tersebut menjadi permasalahan serius dalam menemukan sendiri pemahaman yang lebih pembelajaran menulis karangan argumentasi. mendalam tentang karangan argumentasi, Permasalahan tersebut diakibatkan karena akibatnya siswa kebingungan saat akan pembelajaran yang dilakukan selama ini mulai menulis, siswa tidak tahu harus mulai masih bersifat konvensional. Pembelajaran konvensional adalah pembelajaran yang masih menggunakan cara-cara pembelajaran lama dan cenderung kurang inovatif. Hal ini dapat diamati dari pengakuan siswa setelah mengikuti pembelajaran menulis karangan argumentasi di kelas. Pembelajaran yang dilakukan masih berpedoman pada cara lama, yaitu siswa hanya mendapat penjelasan dan contoh dari sumber pembelajaran berupa modul mata pelajaran bahasa Indonesia. Teknik yang digunakan dalam pembelajaran adalah menggunakan metode konvensional yaitu ceramah.

Dengan tidak adanya teknik dan media lain yang dapat menarik dan memotivasi siswa membuat pembelajaran terasa menjenuhkan. Siswa menjadi objek monoton yang harus diam dan mendengarkan ceramah guru. Teknik pembelajaran yang konvensional ini mengakibatkan pemahaman siswa terhadap karangan argumentasi sangat terbatas, sebab siswa hanya memperhatikan contoh dalam modul pelajaran yang penjelasannya sangat terbatas. Modul dari mana menulisnnya, siswa kebingungan saat menentukan topik dan latar belakang masalah, siswa ragu-ragu saat berargumen, siswa tidak tahu cara menghadirkan konklusi, siswa kesulitan dalam pemilihan bahasa dan tanda baca. Hal ini akan membuat siswa juga tidak memiliki motivasi untuk menulis.

Sesungguhnya banyak upaya yang dapat dilakukan untuk mengatasi permasalahan yang terjadi dalam pembelajaran menulis karangan argumentasi. Di sini penulis ingin mengubah cara pembelajaran menulis karangan argumentasi yang masih konvensional menjadi pembelajaran yang inovatif dengan tujuan agar siswa dapat meningkatkan keterampilan menulis argumentasi. Alternatif cara untuk mengatasinya adalah dengan menggunakan teknik dan media pembelajaran. Di antara sekian banyak model dan media yang dapat dicobakan adalah teknik rekonstruksi dan media majalah dinding, model belajar thing pair share, dan model pembelajaran Berpikir, Barbicara, dan Menulis. 
Berpikir Kritis Terhadap Kemampuan Menulis Argumentasi

Dudu Suhandi Saputra

\section{SIMPULAN}

Berdasarkan hasil analisa yang telah dilakukan, diperoleh bahwa: pertama, hasil menulis argumentasi siswa yang menggunakan metode problem based learning lebih tinggidari pada siswa yang menggunakan metode resitasi. Kedua, tidak terdapat pengaruh interaksi antara metode pembelajaran dengan kemampuan berpikir kritis terhadap kemampuan menulis argumentasi. Ketiga, hasil menulis argumentasi kelompok siswa yang berpikir kritis tinggi dan belajar dengan metode problem based learning lebih tinggi dari pada kelompok siswa yang berpikir tinggi yang belajar dengan metode resitasi. Keempat, hasil menulis argumentasi kelompok siswa yang berpikir kritis rendah dan belajar dengan metode problem based learning lebih tinggi dari pada kelompok siswa yang berpikir kritis rendah yang belajar dengan metode resitasi.

Adapun saran dari hasil penelitian ini sebagai berikut:

1. Bagi sekolah, hendaknya memfasilitasi pembelajaran dengan menggunakan metode problem based learning. Hal ini dikarenakan metode problem based learning dapat meningkatkan keterampilan menulis argumentasi siswa.

2. Guru hendaknya mampu meningkatkan kemampuan berpikir kritis siswa melalui pendekatan-pendekatan pembelajaran yang mampu meningkatkan aktivitas siswa.

3. Melalui penelitian ini, metode problem based learning dapat dijadikan sebagai alternatif dalam pembelajaran di sekolah dasar khususnya mengenai keterampilan menulis argumentasi.

4. Pada peneliti selanjutnya diharapkan meneliti pada aspek keterampilan bahasa yang lainnya di luar keterampilan menulis argumentasi.

\section{DAFTAR RUJUKAN}

Bonef, Marcel, Komik Indonesia. Jakarta : Gramedia, 1998 dalam http://books.google.co.id/books?id= IJ7NbNW0HEC\&pg=PT47\&num= $10 \&$ source $=\mathrm{gbs}$ selected pages \&ca

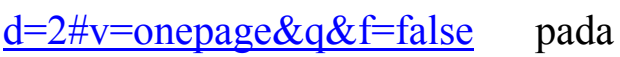
06 Februari 2015

Dhiksy. 2010. Pengaruh strategi pembelajaran dan kemampuan berpikir logis terhadap keterampilan menulis argumentasi. tesis, tidak terbitkan. Jakarta; pasca sarjana UNJ

Hosnan. 2014. Pendekatan saintifik dan kontekstual dalam pembelajaran abada 21. Bogor: ghalia Indonesia

Keraf. 2007. Argumentasi dan narasi. Jakarta; PT. Gramedia pustaka utama 
JURNAL PENDIDIKAN DASAR

Volume 7 Edisi 1 Mei 2016

McCloud, Scout, Understanding Comic,

Jakarta: Kepustakaan Populer

Gramedia, 2001

Mulyasa. 2011. Menjadi guru professional menciptakan pembelajaran kreatif dan menyenangkan. Bandung; PT. Remaja rosda karya

Puspitorini, Retno , A.K. Prodjosantoso,

Bambang Subali, dan Juma, Jurnal : "Penggunaan Media Komik Dalam

Pembelajaran IPA untuk Meningkatkan Motivasi dan Hasil Belajar Kognitif dan Afektif". Yogyakarta : UNY. 2012

Samani, Muchlas dan Hariyanto. 2011. Konsep dan Model Pendidikan Karakter, Bandung : PT.Remaja Rosdakarya,

Tarigan. 2014. Menulis sebagai suatu keterampilan berbahasa. Bandung: Angkasa.

Yaumi, Muhamad. 2012. Pembelajaran berbasis multiple intelegences. Jakarta: Dian Rakya. 